\title{
Cervical Cancer in a Septate Uterus with Double Cervix and Double Vagina: A Case Report and Review of the Literature
}

\author{
Yingxin Gong $\mathbb{D}^{1, *}$, Yu Xie $\mathbb{D}^{1, *}$, Limei Chen ${ }^{1,2}$, Long Sui $\mathbb{D}^{1,2}$ \\ 'Cervical Diseases Center, Obstetrics and Gynecology Hospital of Fudan University, Shanghai, People's Republic of China; ${ }^{2}$ Shanghai Key Laboratory \\ of Female Reproductive Endocrine Related Diseases, Shanghai, People's Republic of China \\ *These authors contributed equally to this work \\ Correspondence: Long Sui; Limei Chen, Obstetrics and Gynecology Hospital of Fudan University, 4I9 Fangxie Road, Shanghai, 2000I I, People's \\ Republic of China, Tel +86 021-33189900, Email suilong@Fudan.edu.cn; limeil II8@foxmail.com
}

\begin{abstract}
Septate uterus with duplicate cervices and double vagina is a rare Müllerian duct anomaly mostly found in labor or gynecological examination. We present a case of a 40-year-old asymptomatic parous patient diagnosed with double cervix and complete vaginal septum. She was admitted to hospital due to abnormal histopathology of suspicious cervical squamous papillary carcinoma post-salpingectomy. Her genital malformation was seriously addressed due to the cervical lesion. The diagnosis of cervical cancer in the left cervix and LSIL in the right cervix was made after LEEP conization. She received laparoscopic hysterectomy with salpingectomy and partial vagina wall resection for radical resection of the lesion. We report this case to present irregular findings during colposcopy, hysterectomy, and histopathology.
\end{abstract}

Keywords: cervical cancer, duplicate cervix, double vagina, Müllerian duct anomaly, septate uterus

\section{Introduction}

Müllerian anomalies, which often refer to congenital malformations of the female reproductive tract, have a prevalence of about 5\%. ${ }^{1}$ According to the 2013 ESHRE/ESGE consensus on the classification of female genital tract congenital anomalies, the uterine abnormalities have six categories, including dysmorphic uterus, septate uterus, dysfused uterus, unilaterally formed-uterus, aplastic uterus, and unclassified malformations. ${ }^{2}$ Septate uterus is caused by resorption defect of Müllerian ducts, leading to a persistent complete or partial longitudinal uterine cavity septum. Women with Müllerian abnormalities can present with miscarriage, infertility and recurrent pelvic pain. ${ }^{3}$ In rare cases, a complete uterocervicovaginal septum was found. A retrospective study reported that $5.9 \%$ of double-chambered uterus cases were complete septate uterus with cervicovaginal septum. ${ }^{4}$ The anomaly is almost asymptomatic and only be found during other gynecological examinations or delivery.

We report a case of a cervical cancer patient with a complete uterine septum and longitudinal vaginal septum, as well as duplicate cervices, double cervical canal, and double vagina. The anomaly diagnosis was confirmed by gynecological examination, ultrasound imaging, magnetic resonance imaging (MRI), and laparoscope. The patient was treated with radical hysterectomy to eliminate the cervical neoplasm and followed up at regular intervals.

\section{Case Report}

A 40-year-old asymptomatic woman diagnosed with cervical squamous cancer was found with a complete septate uterus with double cervix and vagina. The patient came to our clinical center a week after a cervical lesion was identified during post-operative follow-up visit after right salpingectomy for an ectopic pregnancy. She had no symptoms, no abnormal vaginal bleeding or discharging. The patient had normal, regular menses with menstrual cycle of 28 days and 
menstruation of 3-4 days. She had moderate menstruation volume and no dysmenorrhea. The woman had one full-term labor with spontaneous vertex delivery and three abortions (two induced abortions and one rupture of tubal pregnancy). She had no family history of tumor or genital malformation.

The time of first discovery of her genital malformation was uncertain, but it was seriously addressed due to the cervical lesion. Two external cervical Ostia were visible in gynecological examination, transvaginal sonography showed "Y-shaped" endometrium converged near inner cervical ostium and cervical canals length were measured $32 \mathrm{~mm}$. An round shaped intrauterine device (IUD) was detected in the right uterine cavity. The uterus measured $41 \mathrm{~mm}$ in length, $59 \mathrm{~mm}$ in transverse diameter, and $40 \mathrm{~mm}$ in anteroposterior diameter, which was relatively shorter and wider compared to normal uterus. Since MRI was planned to further visualize and classify the malformation, the patient had the IUD removed under ultrasound guidance. During the procedure, the left side cervix presented an immature appearance which was smaller than expected of a normal cervix, and the IUD was removed intact.

MRI showed a $5.0 \mathrm{~cm} \times 6.2 \mathrm{~cm} \times 4.8 \mathrm{~cm}$ uterus with flat fundus and "Y-shaped" cavity, the thickness of the right and the left endometrium were $1.7 \mathrm{~cm}$ and $1.5 \mathrm{~cm}$ with an asymmetric signal in the endometrium and cervical canal. A septum can be seen in the midline of the uterus which extended to the external cervical ostium, the distance between the endometrium of bilateral cornua uteri was $3.6 \mathrm{~cm}$ and its distance to the uterine fundal serosal layer was $1.0 \mathrm{~cm}$. Two cervical canals and a partial septum image in the vagina can be seen. And there was no lymphovascular space invasion identified. No abnormality in the size and shape of both kidneys was observed in the MRI (Figure 1).

The patient received a "three-step" screening procedure for cervical cancer to clarify the condition of cervical lesions. Cytology results of Liquid-based cell testing (LCT) in both cervices were both high-grade squamous intraepithelial lesion (HSIL). Human papillomavirus (HPV) testing of both cervical smears was HPV16 positive. Colposcopy showed a double vagina, duplicate cervices, and HSIL in both cervices. Colposcopy-directed punch biopsy (CDB) and endocervical curettage (ECC) histopathology showed: 1. (LEFT ECC) cervical canal epithelial tissue; 2. (LEFT CDB) exogenous squamous papillary carcinoma located at 1-2 o'clock at the left cervix, and insufficient tissue determining invasion; 3 . (RIGHT ECC) low-grade squamous intraepithelial lesion (LSIL); 4. (RIGHT CDB) LSIL in the right upper lip of the cervix (Figure 2A and B).

To define the degree and invasive extent of the lesion, the patient then received Loop Electrosurgical Excision Procedure (LEEP) conization of the left cervix. The resection began at 3 o'clock of the left cervix, part of the cervical tissue (base width radius $0.8 \mathrm{~cm}$, depth $1.8 \mathrm{~cm}$ ) was cut off, and electrocoagulation was used for hemostasis. The histopathological result showed focal invasive squamous cell carcinoma (invasive depth $2.8 \mathrm{~mm}$ ) with a negative margin (Figure 2C and D). The diagnosis of cervical cancer stage IA1 (FIGO 2018) and stage TIA1N0M0 (AJCC 2017) in the left cervix was made.

As the patient had no fertility demands, Querleu-Morrow type A hysterectomy with salpingectomy (left) and partial vagina wall resection under laparoscopy was performed. Laparoscopy showed normal kidneys and an anteversion uterus with a size close to $4 \mathrm{~cm} \times 5 \mathrm{~cm} \times 4 \mathrm{~cm}$ and regular contour. After laparoscopic examination, coagulated resection was performed along the left mesosalpinx to the left proximal uterine horn. The ovarian ligament, round ligament and part of broad ligament were clamped to the level of uterine isthmus. The bladder peritoneum was opened, both bladderpods were cut by coagulation, and the bladder was pushed down to the anterior fornix of the vagina. The left uterine arteries and veins, parametrium and the uterosacral ligament were cut by coagulation. The anterior wall of the vagina was lifted, then the uterus, cervix, and $2 \mathrm{~cm}$ of the vaginal wall below the external cervix were resected along the vaginal fornix. Absorbable suture was used to continuously suture the vaginal stump. Duplicate cervices and a complete vagina septum were visible after resection. The uterus specimen was $5.0 \mathrm{~cm} \times 6.2 \mathrm{~cm} \times 4.8 \mathrm{~cm}$ in size with a septum extending from the uterine fundus to the cervix. The right uterine cavity measured $7 \mathrm{~cm}$ deep with $0.3 \mathrm{~cm}$-thick endometrium and $1.5 \mathrm{~cm}$-thick posterior muscular layer. The left uterine cavity was $7.5 \mathrm{~cm}$ deep with $0.2 \mathrm{~cm}$-thick endometrium and $1.5 \mathrm{~cm}$-thick posterior muscular layer.

The intraoperative diagnosis was consistent with the preoperative diagnosis and confirmed the diagnosis of the complete septate uterus as well as vagina septum. Microscopic histopathology results showed necrotic and reparative changes of the left cervix after LEEP, and no residual lesions were observed. Chronic inflammation in the right cervix was shown, the excisional margin of the vaginal wall was negative. The cervical squamous column junction was 


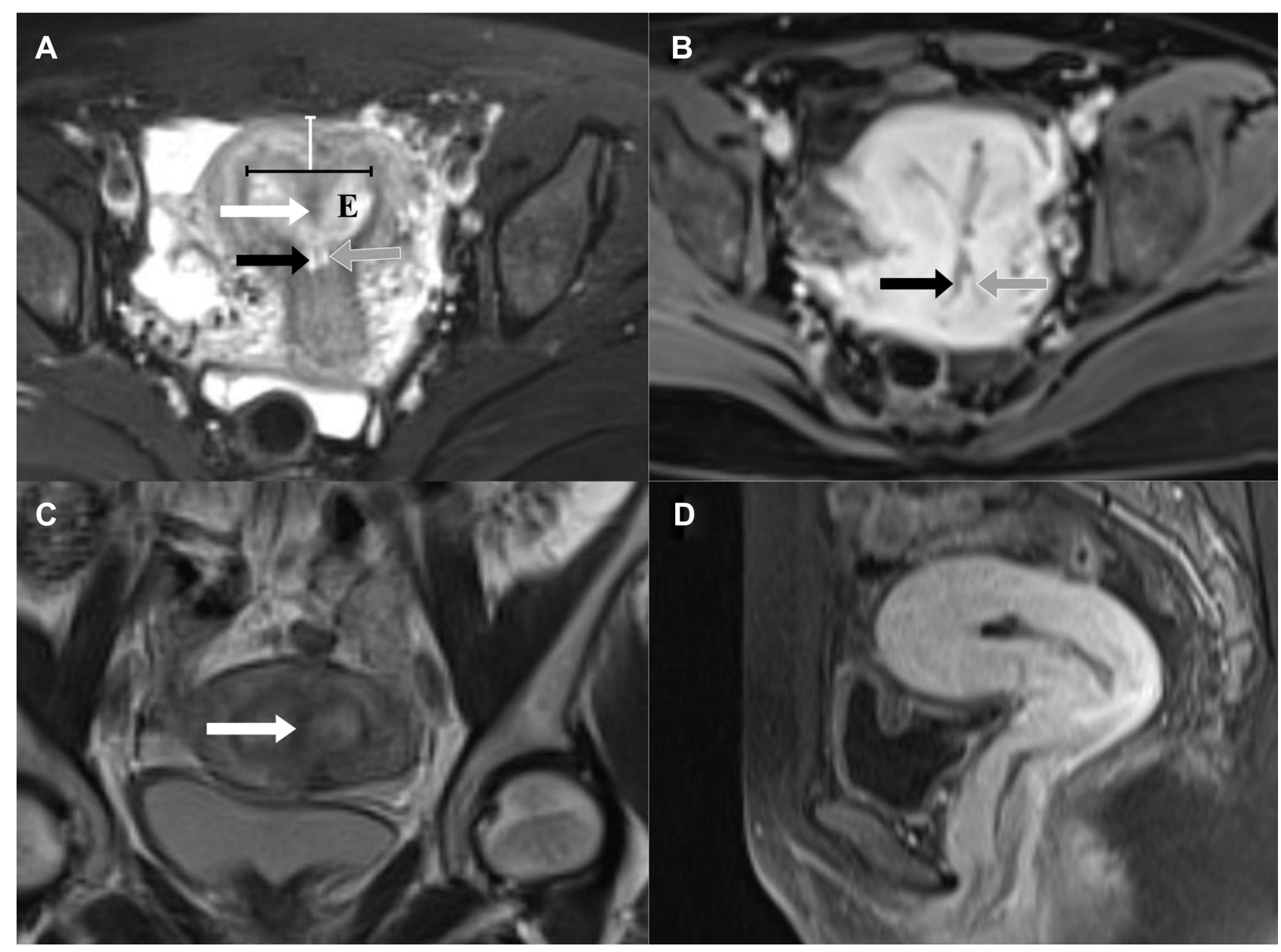

Figure I T2 weighted MRI images of the pelvis. No obvious cervical lesion or lymph node enlargement in the pelvic cavity was observed. (A and B) Axial slice demonstrated two uterine cavities and cervical canals with a flat fundus. A septum can be seen in the midline of the uterus which extended to the external cervical ostium (White arrowseptum; black arrow-right cervical canal; grey arrow-left cervical canal). The distance between the endometrium of bilateral cornua uteri (black line) was $3.6 \mathrm{~cm}$ and its distance to the uterine fundal serosal layer (white line) was $1.0 \mathrm{~cm}$; (C) Coronal slice showed double cervical canals (White arrow-septum); (D) Sagittal slice through cervix and uterus showed no definite lesion in cervix.

separated by the connective tissue septum, which was completely normal (Figure 2E and F). Focal adenomyosis was identified in the right myometrium while no lesion in left myometrium.

The patient's intraoperative bleeding was $150 \mathrm{~mL}$ and the postoperative course was uneventful. The postoperative follow-up 6 month later presented normal cytology and colposcopy result with negative HPV testing. Institutional review board/ethics committee approval of Obstetrics and Gynecology Hospital of Fudan University was obtained for this study and the patient gave her informed consent for publication of this case report.

\section{Discussion}

Congenital genital malformations in women can cause infertility as well as adverse effects on pregnancy especially for women of childbearing age. The incomplete fusion of the paired Müllerian ducts and resorption of the septum is the etiology of the uterus malformation, although the region of fusion and the direction is not well understood. ${ }^{5}$ The anomaly of the longitudinal vaginal septum, double cervix, and complete septate uterus revealed the fusion of the Müllerian duct begins in the isthmic region and moves in both caudal and cranial direction. ${ }^{6}$ This anomaly is not included in the classification of female genital anomaly, but with extended septum to the vagina comparing to complete uterus septum which extended to the outer ostium.

The vaginal septum with complete cervical-uterine septum can be asymptomatic, dyspareunia in nulligravida, abortion or preterm delivery are the main reasons for patients to seek medical advice. ${ }^{7}$ Through the literature review, 


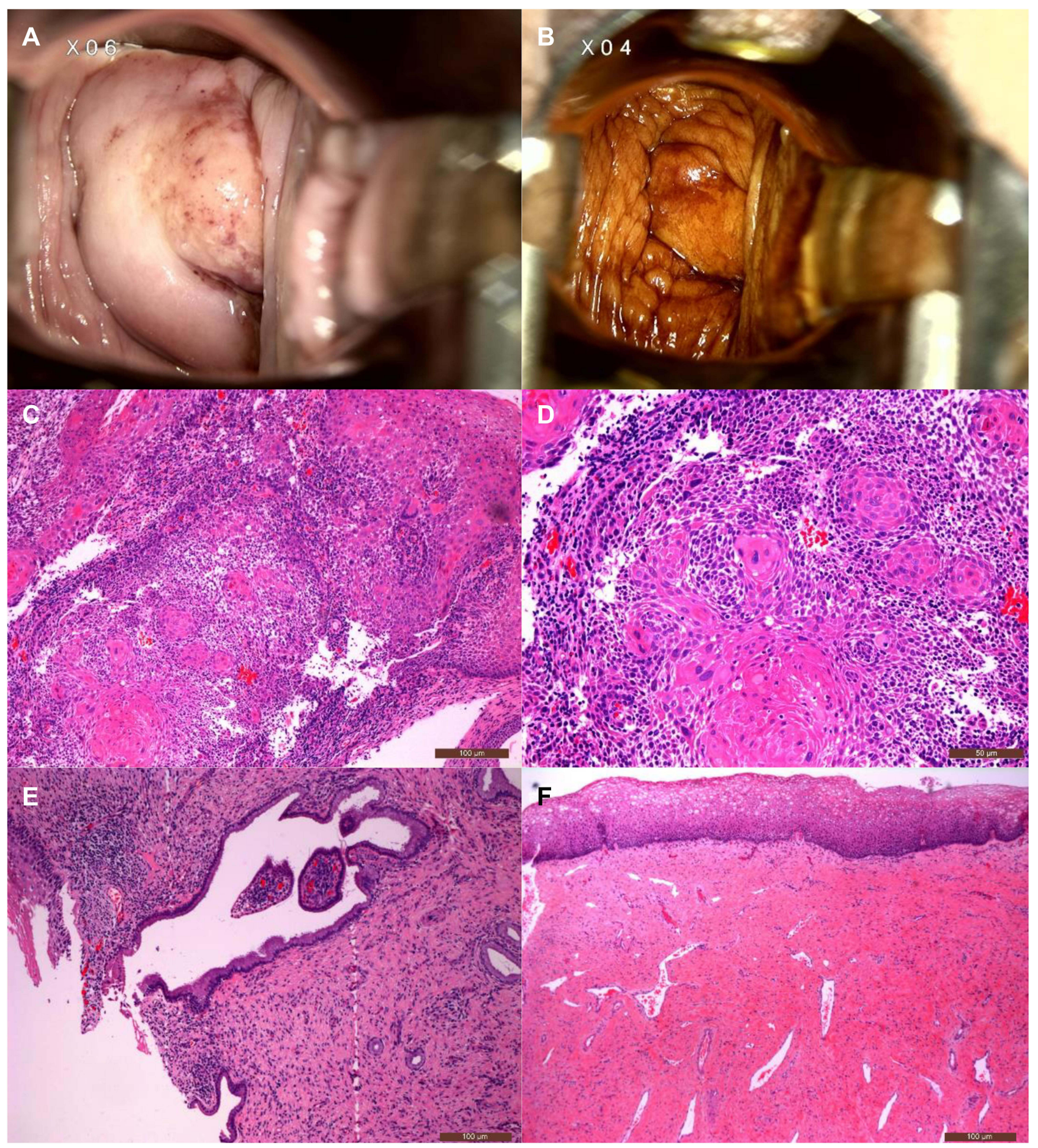

Figure 2 Colposcopic and microscopic view of the exogenous squamous papillary carcinoma at the left cervix. (A) Acetowhite epithelium located at I-2 o'clock under colposcopy; (B) Negative iodine staining area located at I-2 o'clock under colposcopy; (C) Several invasive carcinoma nests can be seen in the conization tissue ( $\times$ I00); (D) Keratin pearls can be seen in carcinoma nests ( $\times 200)$; (E) Cervical squamous column junction was normal $(\times 100)$; (F) Vagina epithelia showed negative excisional margin $(\times 100)$.

we found several similar cases reported worldwide. ${ }^{5,6,8-11}$ The first case of the double uterus and double vagina was reported in 1900, Tindal et al described the detailed examination of the patient's anomaly as septate uterus with a perforated fleshy septum to the left of the vaginal middle line and menstruation came from the right cervical canal. ${ }^{8}$ Most patients were in their twenties with symptoms as dysmenorrhea, metrorrhagia, dyspareunia, and infertility, but some of their symptoms were associated with occlusion of the menstruation. Those patients were mostly diagnosed by 
transvaginal 3D ultrasonography, MRI and hysteroscopy, which showed a longitudinal septum extending through the uterus, cervix, and the proximal vagina with cervical and vaginal duplication. The management of the abnormality varied greatly and required a forum to regulate and facilitate the normalization. ${ }^{12}$

Malignant lesions occurring in Müllerian anomaly create a challenge for gynecologists to manage. Cervical neoplasms occurring in patients with double uterus have been reported previously (Table 1). Most patients have symptoms of abnormal vaginal bleeding or abnormal Pap smear, and the lesion can reside in one or both cervices with different origins. Whether the malformation of duplicate cervices increases the incidence of cervical neoplasm or not is unknown

Table I Summary of Previous Publication of Double Uterus with Cervical Neoplasm

\begin{tabular}{|c|c|c|c|c|c|}
\hline Reference & Age & Parity & Symptom & Pathology of Lesion & Treatment \\
\hline $\begin{array}{l}\text { Wall et al } \\
(1958)^{13}\end{array}$ & 35 & $\begin{array}{l}\text { Gravida } 2, \\
\text { para } 2\end{array}$ & $\begin{array}{l}\text { Intermenstrual spotting for } \\
\text { one year and postcoital } \\
\text { bleeding woth abnormal } \\
\text { Pap smear }\end{array}$ & $\begin{array}{l}\text { Intraepithelial squamous cell } \\
\text { carcinoma in both cervices }\end{array}$ & Total abdominal hysterectomy \\
\hline $\begin{array}{l}\text { Corbett } \\
\text { et al } \\
(1982)^{14}\end{array}$ & 56 & Nullipara & $\begin{array}{l}\text { 5-month history of } \\
\text { intermittent } \\
\text { postmenopausal bleeding }\end{array}$ & $\begin{array}{l}\text { Poorly differentiated invasive } \\
\text { squamous carcinoma at the lower } \\
\text { end of right endocervical canal }\end{array}$ & $\begin{array}{l}\text { Pre-operative radiotherapy followed } \\
\text { by extended hysterectomy with } \\
\text { resection of the vaginal septum and } \\
\text { pelvic nodes }\end{array}$ \\
\hline $\begin{array}{l}\text { Fox et al } \\
(1986)^{15}\end{array}$ & 30 & $\begin{array}{l}\text { Gravida } 3, \\
\text { para } 2\end{array}$ & $\begin{array}{l}\text { Chronic pelvic pain and } \\
\text { abnormal Pap smear }\end{array}$ & $\begin{array}{l}\text { Microinvasive cervical cancer of the } \\
\text { same depth (Stage IAI) on each } \\
\text { side. }\end{array}$ & $\begin{array}{l}\text { Total abdominal hysterectomy with } \\
\text { bilateral salpingo-oophorectomy }\end{array}$ \\
\hline $\begin{array}{l}\text { Tam et al } \\
(1988)^{16}\end{array}$ & 69 & Nullipara & $\begin{array}{l}\text { 4-month history of } \\
\text { postmenopausal bleeding }\end{array}$ & $\begin{array}{l}\text { Squamous cell carcinoma of the } \\
\text { large cell in both cervices and the } \\
\text { soft tissue between the } 2 \text { cervices } \\
\text { involved }\end{array}$ & $\begin{array}{l}\text { Wertheim hysterectomy with partial } \\
\text { resection of the vaginal septum } \\
\text { followed by postoperative } \\
\text { radiotherapy }\end{array}$ \\
\hline $\begin{array}{l}\text { Sugimori } \\
\text { et al } \\
(1990)^{17}\end{array}$ & 44 & $\begin{array}{l}\text { Gravida 2, } \\
\text { para I }\end{array}$ & $\begin{array}{l}\text { Atypical genital bleeding for } \\
\text { several months }\end{array}$ & $\begin{array}{l}\text { Adenocarcinoma in both cervices } \\
\text { (Stage IIB) in both cervix }\end{array}$ & $\begin{array}{l}\text { Radical hysterectomy, postoperative } \\
\text { radiation }\end{array}$ \\
\hline $\begin{array}{l}\text { Sugimori } \\
\text { et al } \\
(1990)^{17}\end{array}$ & 69 & $\begin{array}{l}\text { Gravida } 6, \\
\text { para } 5\end{array}$ & Abnormal Pap smear & $\begin{array}{l}\text { Squamous cell carcinoma in both } \\
\text { cervix }\end{array}$ & $\begin{array}{l}\text { Semi-radical hysterectomy and pelvic } \\
\text { lymph node dissection }\end{array}$ \\
\hline $\begin{array}{l}\text { Bakri et al } \\
(1992)^{18}\end{array}$ & 29 & Nulliparous & Abnormal Pap smear & Carcinoma in situ in both cervices & $\begin{array}{l}\text { Two separate cold-knife conizations in } \\
\text { both cervices }\end{array}$ \\
\hline $\begin{array}{l}\text { Lee et al } \\
(2000)^{19}\end{array}$ & 45 & $\begin{array}{l}\text { Gravida I, } \\
\text { para I }\end{array}$ & $\begin{array}{l}\text { Heavy menstrual and } \\
\text { intermenstrual vaginal } \\
\text { bleeding }\end{array}$ & $\begin{array}{l}\text { Invasive carcinoma on the } \\
\text { anteroinferior left cervix (Stage } \\
\text { IIAI) CIN } 3+\text { on the right cervix }\end{array}$ & $\begin{array}{l}\text { Bilateral cervical loop excisions and } \\
\text { radical radiotherapy to both uteri on } \\
\text { the basis }\end{array}$ \\
\hline $\begin{array}{l}\text { Kimball } \\
\text { et al } \\
(2006)^{20}\end{array}$ & 39 & $\begin{array}{l}\text { Gravida } 2, \\
\text { para } 2\end{array}$ & $\begin{array}{l}3 \text { months of post-coital } \\
\text { bleeding }\end{array}$ & $\begin{array}{l}\text { Squamous cell cancer in the right } \\
\text { cervix (Stage IBI) }\end{array}$ & $\begin{array}{l}\text { Radical hysterectomy with pelvic and } \\
\text { periaortic lymph node dissection }\end{array}$ \\
\hline $\begin{array}{l}\text { Loo et al } \\
(2010)^{21}\end{array}$ & 45 & Nulliparous & $\begin{array}{l}\text { Abnormal cervical } \\
\text { screening }\end{array}$ & $\begin{array}{l}\text { Invasive carcinoma of both cervices } \\
\text { (Stage IIB) }\end{array}$ & Concurrent chemoradiotherapy \\
\hline $\begin{array}{l}\text { Guo et al } \\
(2011)^{22}\end{array}$ & 40 & NS & Abnormal Pap smear & Cervical carcinoma (Stage IIA) & NS \\
\hline $\begin{array}{l}\text { Sparic et al } \\
(20 \mid 7)^{23}\end{array}$ & 53 & $\begin{array}{l}\text { Gravida } 4, \\
\text { para } 2\end{array}$ & $\begin{array}{l}\text { Repeated abnormal Pap } \\
\text { smears }\end{array}$ & $\begin{array}{l}\text { CIN3 in the region where two } \\
\text { endocervical canals conjoined }\end{array}$ & Classical abnormal hysterectomy \\
\hline
\end{tabular}

Abbreviations: CIN, cervical intraepithelial neoplasia; NS, not state. 
as its incidence is rare. In general, the staging principle of cervical cancer in patients with double cervix is similar to normal patients except the lesion in both cervices should be described and staged separately as the lesion of each cervix may in different stage. ${ }^{14,19,20}$ Though lesions of different stages occurred in each cervix, most previously reported cases adopted radical hysterectomy as the therapy of cervical cancer and resection of the vaginal septum was optional. ${ }^{14,16}$ Only one patient with lesion of different stage on each cervix did not receive hysterectomy as it would have required vaginectomy, so bilateral cervical loop excisions were performed, and radical radiotherapy was applied to both uteri in case of cancerous progress. ${ }^{19}$ In some cases, conization can be technically difficult as the aberrant anatomical structure, and the fertility-sparing procedure in early-stage patients with fertility demands has not been reported previously. ${ }^{23}$

In our case, we performed hysterectomy with salpingectomy and partial vagina wall resection to fully eliminate the cervical lesion as the patient had no fertility demand. However, the cervical cancer of StageIA1 can be managed with simple hysterectomy or conization if wish for future fertility, even with double cervices. As the patient was staged TIA1N0M0, pelvic lymph node resection and sentinel lymph node mapping were unnecessary. Cervical cancer occurred in patients with duplicate cervices is rare, here we presented a novel case of cervical cancer in one of the cervical canals in a woman with a complete uterocervicovaginal septum. However, there are some limitations. The patients did not receive genetic testing thus whether genetic factor lead to the malformation and the cervical lesion was not determined. Besides, the patient's previous delivery was not in our hospital, the detailed circumstance was unknown. The present case was not sufficient to conclude the management of cervical lesion on both cervices, and more evidence was required.

\section{Conclusion}

Cervical cancer occurred with the uterine anomaly was seldom reported with discrepant treatment. To explore the optimal therapy, especially for those with fertility demands, additional information from other case reports are needed. More evidence was required before recommendations of management of cervical cancer with uterine anomaly.

\section{Acknowledgments}

This work was supported by the National Natural Science Foundation of China (Grant No. 81701398) and the Science and Technology Commission of Shanghai Municipality (No. 18411963600). The authors thank the Shanghai Key Laboratory of Female Reproductive Endocrine Related Diseases.

\section{Disclosure}

The authors declare that they have no conflicts of interest in this work.

\section{References}

1. Chan YY, Jayaprakasan K, Zamora J, et al. The prevalence of congenital uterine anomalies in unselected and high-risk populations: a systematic review. Hum Reprod Update. 2011;17(6):761-771.

2. Grimbizis GF, Gordts S, Di Spiezio Sardo A, et al. The ESHRE/ESGE consensus on the classification of female genital tract congenital anomalies. Hum Reprod. 2013;28(8):2032-2044.

3. El Saman AM, Shahin AY, Nasr A, et al. Hybrid septate uterus, coexistence of bicornuate and septate varieties: a genuine report. J Obstet Gynaecol Res. 2012;38(11):1308-1314.

4. Haddad B, Louis-Sylvestre C, Poitout P, et al. Longitudinal vaginal septum: a retrospective study of 202 cases. Eur J Obstet Gynecol Reprod Biol. 1997;74(2):197-199.

5. Chang AS, Siegel CL, Moley KH, et al. Septate uterus with cervical duplication and longitudinal vaginal septum: a report of five new cases. Fertil Steril. 2004;81(4):1133-1136.

6. Hundley AF, Fielding JR, Hoyte L. Double cervix and vagina with septate uterus: an uncommon müllerian malformation. Obstet Gynecol. 2001;98 (5 Pt 2):982-985.

7. Patton PE, Novy MJ, Lee DM, et al. The diagnosis and reproductive outcome after surgical treatment of the complete septate uterus, duplicated cervix and vaginal septum. Am J Obstet Gynecol. 2004;190(6):1669-1675.

8. Tindal D. Notes on a Case of Double Uterus (Uterus Septus) and Double Vagina. Glasgow Med J. 1900;54(3):180-183.

9. Pavone ME, King JA, Vlahos N. Septate uterus with cervical duplication and a longitudinal vaginal septum: a müllerian anomaly without a classification. Fertil Steril. 2006;85(2):494.e9-10.

10. Wai CY, Zekam N, Sanz LE. Septate uterus with double cervix and longitudinal vaginal septum. A case report. J Reprod Med. 2001;46(6):613-617.

11. PDC M-B, Okoye EI. Uterus Septus Subtotalis Bicollis: a Rare Mullerian Duct Abnormality. Ann Clin Lab Sci. 2018;48(1):116-119.

12. Grunfeld L, Klein J, Steren C. The management of uterus septus. Fertil Steril. 2004;82(3):766.

13. Wall RL. Didelphic uterus with carcinoma in situ of both cervices. Am J Obstet Gynecol. 1958;76(4):803-806. 
14. Corbett PJ, Crompton AC. Invasive carcinoma of one cervix in a uterus didelphys. Case report. Br J Obstet Gynaecol. 1982;89(2):171-172.

15. Fox S, Mones JM, Kronstadt R, et al. Bilateral and synchronous squamous cell carcinoma of the cervix in a patient with uterus didelphys. Obstet Gynecol. 1986;67(3 Suppl):76-79.

16. Tam G, Rogers M, Arnold M. Invasive carcinoma of both cervices in a patient with uterus didelphys. Aust $N$ Z J Obstet Gynaecol. $1988 ; 28$ (3):239-240

17. Sugimori H, Hachisuga T, Nakamura S, et al. Cervical cancers in uterus didelphys. Gynecol Oncol. 1990;36(3):439-443.

18. Bakri Y, Salem H, Sadi AR, et al. Bilateral and synchronous cervical carcinoma in situ in a didelphic uterus. Int J Gynaecol Obstet. 1992;37 (4):289-291.

19. Lee CD, Churn M, Haddad N, et al. Bilateral radical radiotherapy in a patient with uterus didelphys. Br $J$ Radiol. $2000 ; 73(869): 553-556$.

20. Kimball KJ, Rocconi RP, Straughn JM, et al. Unilateral cervical cancer in a patient with cervix duplex. Gynecol Oncol. 2006;103(1):346-348.

21. Loo HW, Locks SM. Squamous cell carcinoma of the cervix: report of an unusual case of bicornuate bicollis uterus treated with bilateral intracavity brachytherapy. Br J Radiol. 2010;83(991):143-146.

22. Guo LQ, Cheng AL, Bhayana D. Case of the month \#169: septate uterus with cervical duplication and vaginal septum. Can Assoc Radiol J. 2011;62 (3):226-228.

23. Sparic R, Dotlic J, Kovac J, et al. Management of cervical dysplasia in patient with Müllerian anomaly: diagnostic and therapeutic challenges. Eur J Gynaecol Oncol. 2017;38(3):469-472.

\section{Publish your work in this journal}

The International Journal of Women's Health is an international, peer-reviewed open-access journal publishing original research, reports, editorials, reviews and commentaries on all aspects of women's healthcare including gynecology, obstetrics, and breast cancer. The manuscript management system is completely online and includes a very quick and fair peer-review system, which is all easy to use. Visit http://www. dovepress.com/testimonials.php to read real quotes from published authors.

Submit your manuscript here: https://www.dovepress.com/international-journal-of-womens-health-journal 